\title{
Cervical Cancer cT2a2 TNM Finding v7
}

National Cancer Institute

\section{Source}

National Cancer Institute. Cervical Cancer cT2a2 TNM Finding v7. NCI Thesaurus. Code C89490.

Cervical cancer invades beyond uterus but not to pelvic wall or to lower third of vagina. There is no parametrial invasion. Clinically visible lesions more than $4.0 \mathrm{~cm}$ in greatest dimension are present. (from AJCC 7th Ed.) 